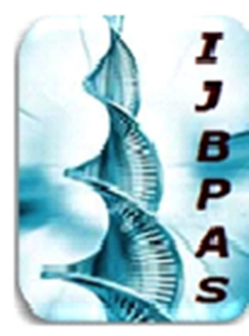

International Journal of Biology, Pharmacy and Allied Seiences (IJBPAS) 'A Bridge Betuen Caboratory and QRader'

Www.ijbpas.com

\title{
CHRONIC TONSILLITIS IN CHILDREN: AN AYURVEDIC
}

\section{APPRAISAL}

\section{ARUN RAJ GR ${ }^{*}$, RASKAR ${ }^{2}$, SHAILAJA $\mathbf{U}^{3}$ AND RAO PN ${ }^{4}$}

1: PhD scholar, Department of Bal Roga, Parul Institute of Ayurved, Parul University, Limda

P.O, Waghodia Taluk - 391760, Vadodara district, Gujarat state, India

2: Associate Professor, Department of Bal Roga, Parul Institute of Ayurved, Parul University, Limda P.O, Waghodia Taluk - 391760, Vadodara district, Gujarat state, India

3: Professor and Head, Department of Kaumarabhritya, Sri Dharmasthala Manjunatheshwara College of Ayurveda and Hospital, Hassan - 573201, Karnataka, India

4: Principal and Chief Medical Officer, Sri Dharmasthala Manjunatheshwara College of

Ayurveda and Hospital, Hassan - 573201, Karnataka, India

*Corresponding Author: Arun Raj GR: E Mail: drdrarunraj26@gmail.com; Ph: 9886292826

Received 25 ${ }^{\text {th }}$ April 2021; Revised 24 $4^{\text {th }}$ May 2021; Accepted $30^{\text {th }}$ June 2021; Available online $1^{\text {st }}$ March 2022

https://doi.org/10.31032/IJBPAS/2022/11.3.5971

\begin{abstract}
Background: Chronic tonsillitis is an inflammation of the tonsils caused by a microbial infection and is usually due to the complication of improperly managed tonsillitis that affects child's day-to-day performances. The patient has a temperature, foul-smelling breath and may feel quite ill. If not managed properly it may lead to systemic disorders namely rheumatic fever, Rheumatic heart disease acute glomerulo-nephritis and even interferes with normal growth and development of child. Materials and Methods: Thorough literary search through various Ayurvedic literatures and databases inclusive of PubMed, PubMed Central, Scopus, Elsevier and others. Discussion and Conclusion: Tundikeri is caused by Kapha and Rakta, and presents with sign and symptoms like swelling, pain, redness, burning and paka (sepsis). Thus, the drugs which pacify Kapha and Rakta are to be used in the management of Tundikeri. Out of abundant drugs mentioned in Ayurvedic texts a few representatives are mentioned here. Most of the drugs discussed here possess Katu, Tikta taste, Ushna Potency, Ruksha, Tikshna, Laghu properties and are pacifier of Kapha, Pitta and Rakta Dosha. Thus, they provide all essential properties required to subvert the pathogenesis of Tundikeri.
\end{abstract}

Keywords: chronic tonsillitis, Ayurveda, tonsil, tundikeri, tonsillitis 


\section{INTRODUCTION}

Tonsillitis is an infection of the tonsils and is one among the common illness during childhood [1]. It causes high morbidity rate in maximum number of children in early years of life but it rarely occurs in children younger than 2 years. It has high incidence in developing country like India. About 7\% visits to paediatricians are only because of tonsillitis [2]. There are about 7,455,494 cases of tonsillitis in India per year and about 200,000 tonsillectomies are performed in India per year [3]. In young children, tonsillitis is one of the recurrent upper respiratory tract infections [4]. Chronic tonsillitis (CHT) is a highly prevalent otolaryngologic diseasein the pediatric age group, and it peaks between 3 and 10 years of age and then declines. CHT is rare in infants and older people [5-6].

The impact of CHT on social, emotional, and financial aspects for family members is so huge [7]. The surface and deep bacterial flora of chronic inflamed tonsils consist of an abundance of probable pathogenic aerobic and anaerobic bacteria, primarily of streptococcal origin [8-12]. Any infection in a growing child usually hampers the immune system and the routine growth and development and when there is repeated attack, it is seen more. Recurrent attack of tonsillitis may sometime act as pyogenic focus for distant infections and has many adverse effects on the normal growth and development of the child [2]. CHT is an inflammation of the tonsils caused by a microbial infection and is usually due to the complication of improperly managed tonsillitis that affects child's day-to-day performances. In streptococcal infection the tonsils often swell and become coated and the throat is sore. The patient has a temperature, foul-smelling breath and may feel quite ill. If not managed properly it may lead to systemic disorders namely rheumatic fever, Rheumatic heart disease acute glomerulo-nephritis and even interferes with normal growth and development of child [1].

Even though exact correlation is not possible, chronic tonsillitis can be simulated with Tundikeri, a Mukharoga (oral disease) explained in various classics [13]. Susrutha considered Tundikeri under Talugataroga (diseases of the palate) while Vagbhata described it under Kantagataroga (diseases of the throat) [14]. Ayurveda explains that it is caused by the vitiation and imbalance of Doshas (bodily humors), i.e., Vata, Pitta, and Kapha. Mainly derangement of Kapha and Rakta (blood) is preceded by impaired digestive capacity (Mandagni/ Vishamagni) and obstruction of channels (Sroto Avarodha) namely Annavaha Srotas (gastrointestinal tract) and Pranavaha Srotas (respiratory tract) which is manifested as difficulty in swallowing, 
mouth breathing, choking spells at night, etc. [15-16].

The current treatment option for CHT is tonsillectomy, but it is not the ultimate solution. The generally accepted criteria for tonsillectomy are at least three to seven episodes of tonsillitis per year in spite of medical therapy, but there is no international consensus [17]. There is rise in number of tonsillectomies over the years [18]. In India up to $2,00,000$ tonsillectomies are being performed per year [19]. Although rare, complications associated with tonsillectomy can be taxing for patients and health care resources [20]. Ayurveda confer an insight to the management of chronic tonsillitis with the use of various local therapies like Kavala, Pratisarana, Gandusha and also valuable oral herbal medicines [21]. These therapies and herbal medicines have effectively been used for centuries without any reported adverse effects [22-25]. Ayurveda can provide a solution to chronic tonsillitis in the form of oral herbal drugs and local application of drugs, thereby preventing tonsillectomy. The paper provides a comprehensive detailing about the disease in the most scientific way. As such, there is no mentioning of specific Nidana (causative factors) for chronic tonsillitis. Instead, the Nidana of Mukha Roga (diseases of oral cavity) is to be taken into consideration.

\section{Mukha Roga Samanya Nidana [26]:}

Aharaja Nidana [27]: Mamsa ofMatsya (fish), Mahisha (buffalo) and Varaha (boar), Anupa Pishitha Mamsa Sevana, Ama Moolaka, soup of Masha (black gram), Dadhi (curd), Ksheera (milk), Suktha (fermented gruel), Ikshu Rasa (sugarcane juice) and Phanitha (half cooked molasses) (Table 1).

Table 1: Properties of AharajaNidanas in Tundikeri [28]

\begin{tabular}{|c|c|c|c|c|c|c|}
\hline S. No. & $\begin{array}{l}\text { Food } \\
\text { items }\end{array}$ & Taste & Quality & Potency & $\begin{array}{c}\text { End of } \\
\text { metabolism }\end{array}$ & Vitiation in Dosha \\
\hline 1. & Matsya & $\begin{array}{c}\text { Madhura } \\
\text { (sweet) }\end{array}$ & - & $\begin{array}{c}\text { Ushna } \\
\text { (hot) }\end{array}$ & Amla (sour) & Pitta andKapha \\
\hline 2. & $\begin{array}{c}\text { Mahisha } \\
\text { Mamsa }\end{array}$ & Madhura & $\begin{array}{l}\text { Guru (heavy), } \\
\text { Snigdha } \\
\text { (unctous) }\end{array}$ & Ushna & - & Kapha, Raktaand Pitta \\
\hline 3. & Masha & Madhura & Guru & Ushna & - & Kapha andPitta \\
\hline 4. & Dadhi & Amla & Guru & Ushna & Amla & KaphaandPitta \\
\hline 5. & Ksheera & Madhura & Snigdha & Ushna & Amla & Kapha \\
\hline 6. & $\begin{array}{l}\text { Iksu } \\
\text { Rasa }\end{array}$ & Madhura & Snigdha, Guru & $\begin{array}{l}\text { Sheeta } \\
\text { (cold) }\end{array}$ & Madhura & Kapha \\
\hline 7. & Phanitha & Amla & Guru & Sheeta & Madhura & Kapha \\
\hline
\end{tabular}

Viharaja Nidana [29]: Avakshayya cleaning teeth daily and Anuchitha (sleeping with face downwards), Dhooma, Chardhana, Gandushaand Dwishatho Dantha Dhavanam - not Siravyadha. 
By constant use of Guru, Madhura, Sheetha, Ruksha Ahara Vihara, sleeping after intake of two types of milk, taking bath after a heavy meal, indigestion, drinking of cold water $\&$ bathing in cold water, intake of too much water after food, Vegadharana, improper sleeping habits, sleeping in lateral position with covered face, in Mandhagni, Vishamashana. Aggravated Vata vitiates upper location of Kapha, conceals the channels \& produces congestion of Srothas, when vitiates the channels of oral cavity - disorders of oral cavity develop [30].

\section{Poorvaroopa:}

As such prodromal symptoms of Tundikeri are not explained in any classical text. As Tundikeri is a disease characterized by Shotha, prodromal symptoms of Shotha is taken into consideration [31] such as Ushma (increased temperature), Sirayama (proceeded by vascular congestion where the Shotha is to occur) and other symptoms may be burning sensation, irritation and discomfort in talu and kanta.

\section{Samprapti of Tundikeri [32]}

Due to indulgence in the etiological factors, KaphaDosha gets vitiated and this vitiated Doshas circulates in the Siras \& gets localised in the Mukha Pradesha As Urdwanga is the prime seat of Kapha. Vitiated Kapha and Raktha Doshas causes a big cystic swelling resembling fruit of Vana Karpasa, associated with burning sensation, pricking pain in the throat and with suppurative cyst.

\section{Samprapti [32]}

The specific Samprapti of Tundikeri is not found in Brihatrayi. The Dosha-Dushya Vivechana of Tundikeri may be understood in following ways:

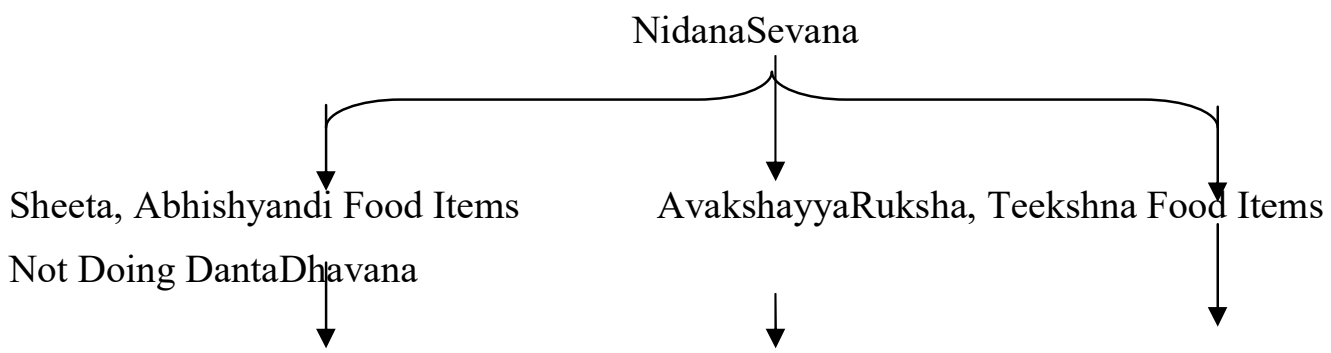

KaphaRaktaDosha Vitiation
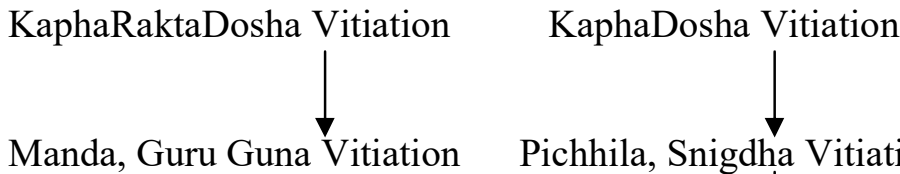

Vata Pitta Dosha Vitiation

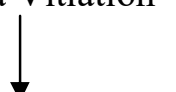

Pichhila, Snigdha Vitiation

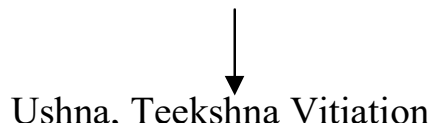

Impairment of Digestive Power (Agni Vikruti - AmaUttpatti)

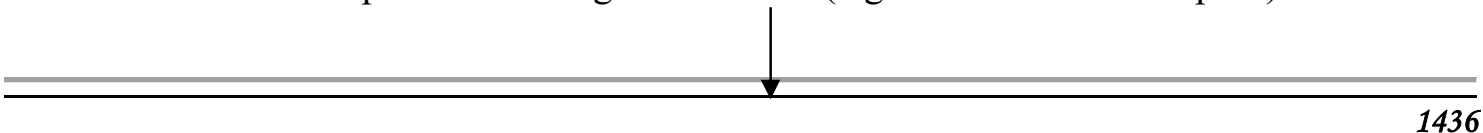


Kha Vaigunya (Obstruction) At Kantha, Talu Leading toDosha-DushyaSammurchhana

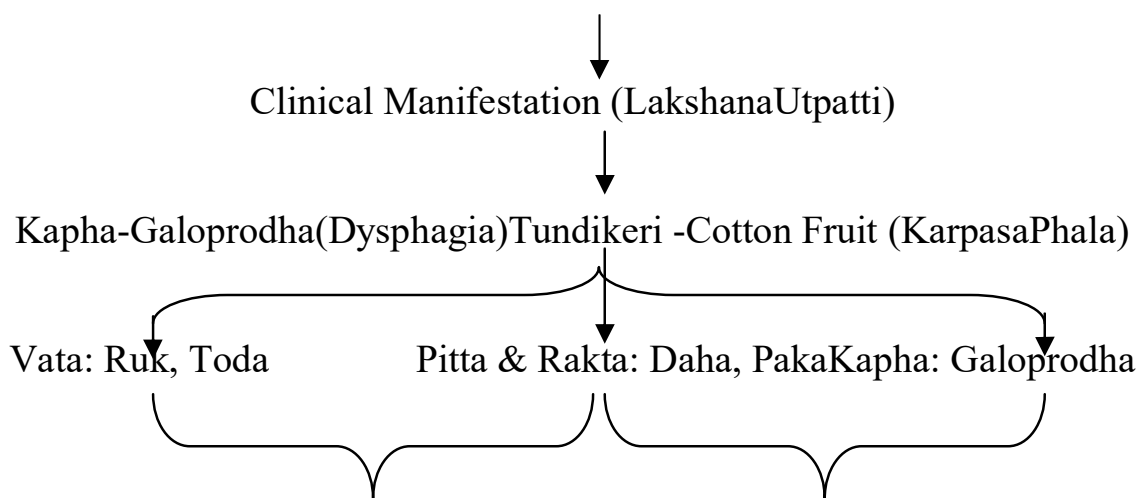

Vata Pittaja Tundikeri Kapha Raktaja Tundikeri

Samprapti Ghataka [32]:

$\checkmark$ Nidana: Kapha, Rakta Prakopaka Ahara and local unhygienic conditions

$\checkmark$ Dosha: Pradhana: Kapha

Anubandhi: Vata, Pitta, Rakta

$\checkmark$ Dushya: Rasa, Rakta, Mamsa.

$\checkmark$ Srotas: Rasavaha, Raktavaha, Mamsavaha

$\checkmark$ Agni: Jataragni, Dhatwagni Mandya

$\checkmark$ Srotodusti: Atipravritti \& Sanga

$\checkmark$ Roga Marga: Bahya

$\checkmark$ Udbhava Sthana: Amashaya

$\checkmark$ Adhistana: Hanusandhi

Types [33]:

$\checkmark$ Vata-Pittaja Tundikeri: If the Tundikeri is associated with Toda and Daha, then it can be taken as Vata-Pittaja Tundikeri

$\checkmark$ Kapha-Raktaja Tundikeri: If the Tundikeri is associated with Sthoola Shotha, Trishna, Shwasa and Kasa then it can be taken as KaphaRaktaja Tundikeri

\section{Lakshana [34]:}

"Hanu Sandhi Ashrithaha KanteKarpasi

Phala Sannibhaha

Picchilo Manda Ruk Shophaha Katinaha Tundikerika"

A swelling caused by vitiation of Kapha and Rakthain the throat (at the root of the palate) which is located at the meeting place of the lower jaw resembling fruit of Karpasa and is slimy and hard to touch, with pricking mild pain burning sensation and suppurationis called Tundikeri.

Sadhyasadhyata: Krichra Sadhya [32]

Mukha Roga Samanya Chikitsa [32]:

Snehana \& Swedana, Shodhana Karma Vamana, Virechana, Nasya, Rakta Mokshana (Tonsils are secondary lymphoid organs \& Rasayana therapy after proper Shodhana helps in Apunarbhavatva and increases Vyadhikshamatwa), Lekhana, Bhedana, Chedana, Pratisarana, Kavala, 
Gandoosha, Dhoomapana, Nasya, Nidana

Parivarjana, Shamana Chikitsa and Samyak

Mukha Prakshalana.

Medicines for gargling / oral intake [32]:

Patoladi Kwatha, Kadiradi Kashaya, Jathyadi Kashaya, Tiladi Kashaya, Darvee Kashaya, Jathipatra Kashaya, Patoladi Gana Kwatha, Triphala Kashaya, Yastimadhu

Kashaya+PanchaLavanas+Water,

TankanaJala.

Churna/ VatiYogas: Kadiradi Vati, Lavangadi Vati, Trijathakadi Vati, Eladi Vati/ Churna, Triphala Churna, Chopacheenyadi Churna, Yastimadhu Churna, Tankanabhasma, Pippalyadichurna, Tejovatyadichurna, Ksharagutika, Kalakachurna, Peethakachurna, Mrudvikadichurna.

Ghrita Pana In MukhaRoga [32]: If there is dryness of palate, who is not suffering from thirst, Uttara Bhakthika Ghrita Pana (ghee should be given for drinking after intake of food) is advised. Later, Navana Nasya (inhalation therapy), Madhura Snigdha Sheeta Rasa is given for intake.

PrathisaranaYogas [32]: Patadi Yoga (Pata, Daruharidra, Kushta, Musta, Manjishta, Katuki, Haridra, Lodhra, Tejobala, Madhu), Kaalakadi Yoga (Gruhadhooma, Rasanjan, Pata, Trikatu, Triphala, Yava Kshara, Loha Bhasma, Chithraka, Tejobala, Madhu), Peethakadi Churna (Daruharidra, Saidhava Lavana, Manashila, Yava Kshara, Haratala, Ghritha,
Madhu), Tankana Bhasma + Madhu, Shubra Bhasma + Madhu, Saindhava Lavana+Madhu.

NasyaYogas [32]: Medicated Ghrita, Taila, Churna can be used accordingly to vitiation of Doshas as nasal drops. Yastimadhu Taila and Ksheerabala Taila can be used.

Kavala Graha containing Thikta Katu Kshoudhra Kashaya. Dhoomapana, Pradhamana, Virechana, Vamana, Langhana - considering the Doshas can be administered.

Other useful Yogas [32]: Lakshmi Vilasa Rasa, Haridra Kanda, Laghu Sootha Shekara Rasa, Arogya Vardhini Vati, SarivadiVati, Gandhaka Rasayana, Kanchanara Guggulu, Sapthamritha Loha.

Vishesha Chikitsaof Tundikeri [32]:

$\checkmark$ Pratisarana: With Gruha Dhooma, Katu Varga Dravyas.

$\checkmark$ Nasya: Taila prepared out of Apamarga Beeja, Vishnukrantha, Danthi, Vidanga, Saindhava Lavana, Tila Kalka.

$\checkmark$ Samanya Mukha Roga Chikitsa can be used.

\section{$\checkmark$ Chedhana Karma [32]:}

If Tundikeri is not cured by Shamana Chikitsa, then Shastra Karma as of Galashundi is to be resorted to (Chedhana Karma). Galashundi (Tundikeri) has to be held firmly with Samdhamsha Yantra \& with Mandalagra Shastra, 
the lower $1 / 3^{\text {rd }}$ part is to be cut by leaving upper $2 / 3^{\text {rd }}$ part. Excessive cutting causes complications of bleeding \& improper cutting causes complications like Lala, Nidra, Bhrama, Tama. As Paschat Karma, application of Kalka made of Maricha, Athivisha, Pata, Vacha, Kushta, Kutannata, Lavana mixed with honey is to be done. Gargling should be done with Kashaya of Vacha, Athivisha, Pata, Rasna, Katurohini \& Pichumanda. Varthi/ Vati prepared out of Ingudi, Kinihi, Danti, Trivrit, Suradaru should be kept in mouth, followed by Kaphaghna Dhoomapana, twice a day.

Pathya: Yavakshara Siddha MudgaYusha. While mentioning about TaluRogaChikitsa, Galashundi Chikitsa is being explained.The same measures of treatment as mentioned for Galashundi should be used in Tundikeri.

- Galashundi (Tundikeri) should be excised \& Gharshana with Trikatu, Vacha, SaidhavaLavana with honey

- Churnas of Kushta, Maricha, Vacha, Saindhava Lavana, Pippali, Pata, Musthaka mixed with honey is used for Gharshana

- Siravyadha in Upanasa destroys Galashundi (Tundikeri)
- Shephali Moola Charvanam

- Vachadi Kavala: Kashaya of Vacha, Athivisha, Pata, Rasna, Katuka, Nimba

- Pathya: Kshara Siddha Mudhga Yusha

Pathya [32]: As such there is no direct reference for Pathya in Tundikeri. Pathya dealt in Mukharoga should be considered. Excess use of certain vegetarian food articles - Trinadhanya, Yava, Mudga, Kulatha, Karavellaka, Patola, Karpoora Jala, Tambula, Ushnajala, Khadira, Ghrita. Bahupatra and Katu-Tikta Rasa predominant Dravya. Excess use of certain non-vegetarian food articles - Jangala Mamsarasa. The patient is advised not to take the food articles which cause Dosha vitiation and the food which is devoid of Abhishyanda Guna. The food articles like Peya, Vilepi, Odana, etc. which are liquid or semisolid and easily digestible. Anabhishyandi and Doshanashaka food and behavioral regimens can be advised for the person who is under Pratisarana.

Apathya [32]: As such there is no direct reference for Apathya in Tundikeri, the Apathya dealt in Mukharoga should be considered. Excess use of certain vegetarian food articles - Dadhi, Dugdha, Guda, Masha, Guru-Abhishyandi, RukshaKathina food articles, Amlarasa Pradhana Dravya. Excess use of certain non- 
vegetarian food articles - Matsya, Anupa

Mamsa. Vihara - Snana (i.e. head bath), use of hard brushing sticks, Divaswapna, Adhomukha Shayana (sleeping with face in downward position).

\section{CONCLUSION}

Tundikeri is caused by Kapha and Rakta, and presents with sign and symptoms like swelling, pain, redness, burning and paka (sepsis). Thus the drugs which pacify Kapha and Rakta are to be used in the management of Tundikeri. Out of abundant drugs mentioned in Ayurvedic texts a few representatives are mentioned here. Most of the drugs discussed here possess Katu, Tikta taste, Ushna Potency, Ruksha, Tikshna, Laghu properties and are pacifier of Kapha,Pitta and Rakta Dosha. Thus, they provide all essential properties required to subvert the pathogenesis of Tundikeri. Moreover, recent experimental, animal and clinical studies have proven the positive effect of various Ayurvedic herbs in the management of tonsillitis. These drugs possess various properties like antiinflammatory, antimicrobial, antiviral, analgesic, antipyretic, antioxidant and immuno-modulatory effect. These properties prevent recurrent infection of tonsils and also reduce as well as cure the acute symptoms like inflammation, swelling, pain, fever etc.

ACKNOWLEDGEMENT
Authors are highly grateful to the constant support and guidance of Dr. Prasanna N Rao, Principal, Sri Dharmasthala Manjunatheshwara College of Ayurveda and Hospital, Hassan, Karnataka and Dr Hemanth Toshikane, Dean, Faculty of Ayurved, Parul Institute of Ayurved, Vadodara, Gujarat.

\section{REFERENCES}

[1] Klaus Stelter. Tonsillitis and sore throat in children.GMS Curr Top Otorhinolaryngol Head Neck Surg. 2014; 13: Doc07.

[2] Vijayakumar Nayak, Vinod Jadhav, Sajjanshetty MR. Traditional medicine in the management of Recurrent Tonsillitis - An Ayurvedic Perspective. J Ayurveda Integr Med Sci 2017; 6: 98-106.

[3] Tarak R. Adhvaryu, K. S. Patel, V. K. Kori, S. Rajagopala, and R. Manjusha. Evaluation of the effect of Kanchnara

Guggulu and Tankana-Madhu

Pratisarana in the management of Tundikeri (tonsillitis) in children. Ayu. 2016 Jul-Dec; 37(3-4): 190197.

[4] G.R. Arun Raj, U. Shailaja, Parikshit Debnath, Subhadip Banerjee, Prasanna N. Rao. Exploratory studies on the therapeutic effects of Kumarabharana Rasa in the 
management of chronic tonsillitis among children at a tertiary care hospital of Karnataka.J Tradit Complement Med. 2016 Jan; 6(1):29-33.

[5] Sangar B., Genaw I. Role of adenotonsillectomy in the quality of life in the children with obstructive sleep apnoea at Al-Khoms hospital, Libya. Int J Otolaryngol Res. 2013; 1: 31-35.

[6] Kliegman R.M., Behrman R.E., Jenson H.B., Stanton B.F. 18th ed. Elsevier; New Delhi: 2008. Nelson Textbook of Pediatrics.

[7] Roos K., Claesson R., Perrson U., Odegaard K. The economic cost of a streptococcal tonsillitis episode. Scand J Prim Health Care. 1995; 13: 257-260.

[8] Surow J.B., Handler S.D., Telian S.A., Fleisher G.R., Baranak C.C. Bacteriology of tonsil surface and core in children. Laryngoscope. 1989; 99: 261-266.

[9] Gaffney R.J., Freeman D.J., Walsh M.A., Cafferkey M.T. Differences in tonsillar core bacteriology in adults and children: a postoperative study of 262 patients. Respir Med. 1991; 85: 383-388.

[10] Mitchelmore I.J., Reilly P.G., Hay A.J., Tabaqchali S. Tonsil surface and core cultures in recurrent tonsillitis: prevalence of anaerobes and beta-lactamase producing organisms. Eur J Clin Microbiol Infect Dis. 1994; 13: 542-548.

[11] Brook I., Yokum P., Foote P.A. Changes in the core tonsillar bacteriology of recurrent tonsillitis: 1977-93. Clin Infect Dis. 1995; 21: 171-176.

[12] Stjernquist-Desatnik A., Holst E. Tonsillar microbial flora: comparison of recurrent tonsillitis and normal tonsils. Acta Otolaryngol (Stockh) 1999; 119: 102-106.

[13] Arun Raj GR, Shailaja U, Rao Prasanna N, Debnath Parikshit. Chronic tonsillitis in children: an ayurvedic bird view. International Ayurvedic Medical Journal 2013; 1(4).

[14] Ramudu KR, Rao MP. A Critical Study OnGrandhigna Karma And Proposition Of Drug Selection W.S.R. To Tundikeri (Tonsillitis). International Journal of Ayurvedic and Herbal Medicine 6: 4(2016) $2277-2284$.

[15] Acharya J.T. $1^{\text {st }}$ ed. Chaukhambha Surbharati Prakashan; Varanasi: 2003. Sushruta Samhita of Sushruta. 
[16] Bhisagacharya H.P. $1^{\text {st }}$ ed. Krishnadas Academy; Varanasi: 2000. Astanga Hridaya.

[17] Paradise J.L., Bluestone C.D., Bachman R.Z. Efficacy of tonsillectomy for recurrent throat infection in severely affected children. Results of parallel randomized and nonrandomized clinical trials. New Engl J Med. 1984; 310: 674-683.

[18] Millington AJ, Phillips JS. Current trends in tonsillitis and tonsillectomy.Ann R Coll Surg Engl. 2014 Nov; 96(8): 586-589.

[19] Woolford TJ, Hanif J, Washband S, Hari CK, Ganguli LA. The effect of previous antibiotic therapy on bacteriology of the tonsils in children, Int J Clin Pract. March 1999; 53 (2): 96-98.

[20] Johnson LB, Elluru RG, Myer CM $3^{\text {rd }}$ Complications of adenotonsillectomy. Laryngoscope . 2002; 112 (8 Pt 2 Suppl 100): 3536.

[21] Sushruta, Sushruta Samhita, Sushrutavimarshini- hindi commentary by Anant Ram Sharma, Chaukhamba Surbharati Prakashan, Varanasi, 2001, volume II, chikitsasthanch. 22, shloka 50-57, page 345 .
[22] Shailaja U, Rao Prasanna N, Arun Raj GR, Mallannavar V. Effect of Kumarabharana Rasa on Chronic Tonsillitis in children: A pilot clinical study. Int. J. Res. Ayurveda Pharm. 2013;4(2):153157.

[23] Arun Raj G R, Shailaja U, Rao Prasanna N, Mallanavar V. Review on the therapeutic efficacy of an Ayurvedic compound drug in Chronic Tonsillitis in children. Unique Journal of Pharmaceutical \& Biological sciences 2013; 1(2): 2-11.

[24] Jyolsna Krishna G, Jithesh Raj KT, Arun Raj GR, Vijayalaxmi M, Shailaja U. Patolashuntyadi yoga in the management of Tundikeri (tonsillitis): A pharmacological appraisal. Aryavaidyan. 2016 Nov - 2017 Jan; 30(2): 38-43.

[25] Jithesh Raj KT, Vijayalaxmi Mallannavar, Arun Raj GR, Shailaja U, Deepthi Viswaroopan, Jyolsna G Krishna. Exploratory studies on the therapeutic effects of Patoladi syrup in the management of chronic tonsillitis in children at a tertiary care hospital of Southern India. Int. J. Res. Ayurveda Pharm. 2018; 9(2): 62-69. 
[26] KR Srikantamurthy. Astanga Hridayam, Uttara Sthana, Mukharoga Vignjaniya Adhyaya.

Vol 3. Ed. 1. Varanasi. Krishna

Das Academy. 1995.

[27] KR Srikantamurthy. Madhava Nidanam, Mukha Roga Nidanam. Varanasi. Chaukhambha Orientalia. 2011 .

[28] Vagbhatta. Ravidutta Tripathi Ed. Ashtanga Sangraha With Vidyotini Hindi Commentary. 10th Ed. Varanasi. Chaukhambha Sanskrita Samsthana. 1999.

[29] KR Srikantamurthy. Madhava Nidanam, Mukha Roga Nidanam. Varanasi. Chaukhambha Orientalia. 2011.

[30] PV Tewari. Kashyapa Samhitha, Chikitsa Sthana, Pratishyaya Chikitsa Adhyaya. Varanasi. Chaukhambha Visvabharati. 2008.

[31] Agnivesha. Charaka Samhita With Vaidyamanorama Hindi Commentary, Volume - Ii, Chikitsasthana $12^{\text {th }}$ Chapter $7^{\text {th }} \quad$ Shloka. Edited By Acharya Vidyadhara Shulka, Ravi Dutt Tripathi. $1^{\text {st }}$ Ed. Varanasi: Chaukhamba Sanskrita Samsthana; Reprint 2006.

[32] Arun Raj G R. A clinical study on the effect of Kumarabharana Rasa in the management of Tundikeri (chronic tonsillitis) [PG thesis].
Karnataka: Rajiv Gandhi

University of Health Sciences; 2014.

[33] Bramhanand Tripathi Ed. Madhava. Madhava Nidaana With Madhukosha Commentary. Vol 2, 56th Chap, 33rd Shloka. $1^{\text {st }}$ Ed. Varanasi: Chaukhamba Surbharati Prakashan. 2003.

[34] Bhagwan Dash. Lalitesh Kashyap. Diagnosis and Treatment of Diseases In Ayurveda. Part 5. Series 7. New Delhi. Ashok Kumar Mittal Concept Publishing Company. 1991. 